Article

\title{
Livelihood Adaptation of Rural Households under Livelihood Stress: Evidence from Sichuan Province, China
}

\author{
Xue Yang ${ }^{1}$, Shili Guo ${ }^{2}$, Xin Deng ${ }^{3}$ D and Dingde Xu ${ }^{1,4, *(D)}$ \\ 1 College of Management, Sichuan Agricultural University, Chengdu 611130, China; yangxue@stu.sicau.edu.cn \\ 2 China Western Economic Research Center, Southwestern University of Finance and Economics, \\ Chengdu 610074, China; guoshili@swufe.edu.cn \\ 3 College of Economics, Sichuan Agricultural University, Chengdu 611130, China; dengxin@sicau.edu.cn \\ 4 Sichuan Center for Rural Development Research, College of Management, Sichuan Agricultural University, \\ Chengdu 611130, China \\ * Correspondence: dingdexu@sicau.edu.cn; Tel.: +86-134-0859-8819
}

Citation: Yang, X.; Guo, S.; Deng, X.; $\mathrm{Xu}, \mathrm{D}$. Livelihood Adaptation of Rural Households under Livelihood Stress: Evidence from Sichuan Province, China. Agriculture 2021, 11, 506. https://doi.org/10.3390/ agriculture11060506

Academic Editors: Gordon Rausser and WIlliam Foster

Received: 20 May 2021

Accepted: 28 May 2021

Published: 30 May 2021

Publisher's Note: MDPI stays neutral with regard to jurisdictional claims in published maps and institutional affiliations.

Copyright: ( $\odot 2021$ by the authors Licensee MDPI, Basel, Switzerland. This article is an open access article distributed under the terms and conditions of the Creative Commons Attribution (CC BY) license (https:// creativecommons.org/licenses/by/ $4.0 /)$.
Abstract: The welfare of many poor and low-income rural households is vulnerable to earthquakes and secondary geological disasters. The academic literature, however, pays little attention to the livelihood pressure, adaptability, and livelihood strategies of these households. Based on the survey data of 327 rural households in the Wenchuan and Lushan earthquake-stricken areas in the Sichuan Province, the livelihood pressure, adaptability, and livelihood strategy characteristics of rural households were analyzed, and the disordered multi-classification logistic regression model was constructed to explore the correlation between the above-mentioned variables. The results show that: (1) Rural households face the greatest economic pressure and the least social pressure; rural households have the strongest adaptability in social capital and the lowest adaptability in financial capital. The proportion of rural households that chose the aid livelihood strategy was the highest, while the proportion of rural households that chose the adjustment livelihood strategy was the lowest. (2) Compared with the expanded livelihood strategy, (a) When the health pressure is higher, the rural households are more inclined to choose the expanded livelihood strategy, followed by the contractive livelihood strategy and, finally, the aid livelihood strategies; (b), the higher the physical capital, the more often the rural households tend to choose the expanded livelihood strategy compared to the adjustment livelihood strategy; (c), The higher the financial capital of farm households, the more they prefer contractive livelihood strategies compared to the expanded livelihood strategy and (d), compared with the aid livelihood strategy, rural households with greater economic pressure are more inclined to choose the expanded livelihood strategy. This study can provide a reference for the establishment of relevant policies related to the adaptation capacity of rural households in the earthquake hazard zone.

Keywords: livelihood pressure; livelihood adaptability; livelihood strategies; earthquake disaster areas; Sichuan

\section{Introduction}

The frequency of extreme weather events (e.g., extreme rainstorms, droughts, hurricanes, etc.) and the severity of disaster-causing events are expected to increase globally as climate change intensifies [1-3]. According to statistics, extreme weather events related to climate change increased by 50\% between 1950 and 1990 [4]. From 2000 to 2019, the number of natural disasters around the world soared from 3656 to 6681, with the number of people affected rising from 3.2 billion to 3.9 billion, according to the report Human Losses from Disasters 2000-2019 released by The United Nations Office for Disaster Risk Reduction. In developing countries, on the other hand, natural disasters caused by climate change will lead to food crops reduction and even threaten national food security due to the lack of a sound disaster prevention and mitigation system [5]. In China, for example, meteorological 
disasters caused crop damage of 19.96 million hectares and direct economic losses of up to 368.1 billion Yuan in 2020 alone, according to the data of the China Climate Bulletin. Geological disasters and secondary disasters caused by climate change have an increasingly serious impact on people's production and life [6,7]. In particular, extreme rainstorm events, due to their short duration and high intensity, easily cause mountain torrential floods, landslides, and debris flows in geological disaster areas, causing huge casualties and property losses [8-10]. According to statistics, the global economic losses caused by mountain torrents alone have reached 46 billion USD a year in the 21st century [11]. However, according to existing studies, the academic research on earthquake disaster risk management is mostly concentrated in developed countries [12,13], and there are relatively few studies on disaster risk management for residents in earthquake-threatened areas in China [14-16].

Poverty, as an objective social phenomenon, is a long-standing problem that hinders the development of human civilization [17-21]. The increase in extreme weather and climate events caused by global climate change has contributed to food insecurity and poverty and has questioned the sustainable livelihoods of small farming communities, especially in developing countries [22]. As the basic units of production and life, rural households are extremely vulnerable to multiple risks, such as climate change, natural disasters, and disease outbreaks [23-27]. Therefore, the shocks of increasing natural disasters outside the system and the long-established poverty inside the system tend to form a vicious cycle. It is of great significance to understand what livelihood strategies rural households tend to choose to deal with internal and external pressures and improve their adaptability.

Under the background of global climate change, scholars have done a lot of research on livelihood adaptation from different perspectives. The research topics mainly include the driving mechanism of livelihood strategy, exploring the impact of rural households' assets and risks on livelihood strategy $[11,28,29]$. The research topics mainly include livelihood resilience, exploring how individuals, communities, or countries use the comprehensive functions of adaptation, absorption, and transformation capabilities at different levels to improve livelihood resilience [30-32]; The research topics also include the calculation of livelihood vulnerability indices, establishing a livelihood vulnerability indicator system from three perspectives of exposure, sensitivity, and adaptation and quantifying vulnerability indicators with a view to develop differentiated livelihood strategies for different sensitive areas [33-35]. The study subdivides generalized agriculture (such as agriculture, forestry, animal husbandry, sideline, and fishery) and develops matching livelihood strategies for different types of farmer groups [36-38]. These studies play an important role in understanding the behavioral logic behind the choice of livelihood strategies of farm households [39-42]. Among them, timely adjustment of livelihood strategy is the most effective way to provide protection against stress for individuals and households [24,43,44], and it is also the key to the study of livelihood adaptability. Under the background of extensive environmental pressure, there have been many types of research on livelihood strategy in the academic circle [45-47], which mostly focus on floods [48-50], droughts [39], storm surges [51], hurricanes [52], and other disasters. The research contents mainly involve the correlation between livelihood capital and livelihood strategy [53], the impact of livelihood risk on livelihood strategy [54], and the measurement of livelihood vulnerability [55]. Therefore, research on rural households' livelihood strategies under the background of earthquake disasters needs to be supplemented and improved $[16,56]$, the characteristics of livelihood pressure, livelihood adaptability, and livelihood strategy choice of rural households and the correlation among them need to be further explored.

China is a mountainous country, affected by topography and geomorphology; many mountain settlements have become prone to earthquakes causing serious loss of life and property to local residents [56-60]. Among those areas, Sichuan is the most typical. According to statistics, from the year 2000 to 2018, Sichuan has experienced 20 earthquakes of magnitude 5 or higher, ranking first in the country, resulting in 460,000 casualties and 
direct economic losses of 939 billion Yuan [61]. Constrained by resource endowments, these regions are usually also poverty-concentrated areas or areas prone to return to poverty [62-66]. According to the survey conducted by the Poverty Alleviation Office of the State Council of China, 20\% of poor rural households are poor due to disasters [67]. 2020 is the year of comprehensive well-off in China [55]. After a comprehensive well-off, it is necessary to continue to pay attention to the groups that are vulnerable and easily returned to poverty. Improving their adaptability through different livelihood strategies (e.g., education, vocational training, etc.), stabilizing their financial situation, and securing their sound development are key to the sustainable development and progress of society [68-75]. Therefore, the mountainous settlements, especially the rural settlements in the earthquake disaster-threatened areas are a special group, which needs special attention because of their poverty and earthquake disasters (including geological secondary hazards) $[57,58,66,76,77]$.

Based on this, this study took 327 rural households in Wenchuan and Lushan, two earthquake-stricken areas in Sichuan Province, as the research object, focusing on their livelihood pressure, adaptive capacity, and livelihood strategy choices, and constructed a disordered multi-classification logistic regression model to investigate the correlation between the above factors, in order to provide a reference for the formulation of policies for the adjustment of regional households' adaptability.

\section{Data and Methods}

\subsection{Data Sources}

The data used in this study came mainly from a questionnaire survey conducted by the Rural Development Research Group of Sichuan Agricultural University in July 2019 in Wenchuan and Lushan earthquake-stricken areas. In order to ensure the typicality and representativeness of the samples, the research group adopted the method of stratified random sampling. Firstly, according to the differences in economic development levels, two counties were selected as sample counties from each of the Wenchuan and Lushan earthquake-stricken areas, and, finally, Beichuan and Pengzhou were selected from the earthquake-stricken areas of Wenchuan county, while Lushan and Baoxing counties were selected from the Lushan earthquake-stricken area. Secondly, according to the economic development level of villages and towns in the sample counties, the distance of townships from the county center, and the disaster losses, the townships in each sample county were divided into two groups, one township from each group was randomly selected as the sample township, and, finally, eight sample townships were obtained. Thirdly, according to the economic development levels of the villages in the sample towns, the distance from the villages to the town center, and the number of people affected by the disaster, the villages in each town were divided into two groups, and one village from each group was randomly selected as the sample village, and finally 16 sample villages were obtained. Finally, according to the number of people affected by the disaster in the villages, combined with the random number table, 20-23 rural households were selected from the rural household register as the sample farming households. Finally, through the investigation, 327 valid questionnaires were obtained from 16 villages in 8 townships of 4 districts and counties.

\subsection{Measurement of Variables}

\subsubsection{Livelihood Pressure}

Livelihood pressure refers to the internal and external risk shocks to which farm households are exposed in their productive lives. Referring to the division of livelihood risks by studies such as by Su et al. [55] and Zeng et al. [56] and taking into account the actual situation in the study area, this study intended to measure the livelihood pressures faced by rural households from four dimensions: natural, economic, social and healthrelated (Table 1). Among them, natural pressure refers to the impact of disasters on rural households' life and production, which is measured taking into account whether the households face extreme weather, earthquakes, geological disasters, environmental 
pollution, pests, and diseases. Economic pressure refers to the economic impact faced by rural households in their daily life activities and it is measured considering whether they suffer from the price fluctuation of agricultural products at home and abroad, fake agricultural products, shortage of funds and the difficulty of financing. Social pressure refers to the impact of the rural households in the social relations, mainly measured taking into account whether the households suffer from low social status, lack of basic pension, medical insecurity, and other shocks to measure. Health pressure refers to the impact on rural households' health, which reflexes whether they suffer from diseases and whether the village health system is perfect.

Table 1. Evaluation index system of farmer households' livelihood pressures.

\begin{tabular}{|c|c|c|c|c|c|}
\hline Dimensions & Variable & Variable Definition and Description & Mean & SD & Weight \\
\hline \multirow{5}{*}{$\begin{array}{l}\text { Natural } \\
\text { pressure }\end{array}$} & $\begin{array}{l}\text { Environmental } \\
\text { pollution }\end{array}$ & $\begin{array}{l}\text { Whether they had suffered from major } \\
\text { livestock diseases or dysentery, } \\
\text { or major industrial contamination (no =0, } \\
\text { yes }=1 \text { ) }\end{array}$ & 0.10 & 0.30 & 0.165 \\
\hline & Extreme weather & $\begin{array}{l}\text { Whether extreme weather (such as heavy } \\
\text { rainfall and frost) had an impact } \\
\text { on their production and life (no = 0, yes = 1) }\end{array}$ & 0.70 & 0.46 & 0.025 \\
\hline & Geological disasters & $\begin{array}{c}\text { Whether geological disasters (such as } \\
\text { earthquakes, landslides, and debris flow) } \\
\text { have had an impact on their production and } \\
\text { life (no }=0 \text {, yes }=1 \text { ) }\end{array}$ & 0.80 & 0.40 & 0.016 \\
\hline & Water resources & $\begin{array}{l}\text { Whether water resources can meet their basic } \\
\text { needs for production and living } \\
\text { (no }=0 \text {, yes }=1 \text { ) }\end{array}$ & 0.95 & 0.22 & 0.004 \\
\hline & $\begin{array}{l}\text { Plant diseases } \\
\text { and insect pests }\end{array}$ & $\begin{array}{l}\text { Whether there have been any pest or disease } \\
\text { outbreaks }(\text { no }=0 \text {, yes }=1)\end{array}$ & 0.48 & 0.50 & 0.052 \\
\hline \multirow{5}{*}{$\begin{array}{l}\text { Economic } \\
\text { pressure }\end{array}$} & $\begin{array}{l}\text { Fluctuations in } \\
\text { prices }\end{array}$ & $\begin{array}{l}\text { Whether their agricultural production is } \\
\text { impacted by fluctuations in agricultural } \\
\text { commodity prices (no }=0 \text {, yes }=1 \text { ) }\end{array}$ & 0.30 & 0.46 & 0.086 \\
\hline & $\begin{array}{l}\text { Fake agricultural } \\
\text { products }\end{array}$ & $\begin{array}{l}\text { Whether they have encountered fake } \\
\text { agricultural products (such as fake pesticides, } \\
\text { fake fertilizers) (no = } 0 \text {, yes }=1 \text { ) }\end{array}$ & 0.16 & 0.36 & 0.132 \\
\hline & Lack of funds & $\begin{array}{l}\text { Lack of funds to scale up agricultural } \\
\text { production }(\text { no }=0, \text { yes }=1)\end{array}$ & 0.65 & 0.48 & 0.030 \\
\hline & Financing & Difficulty to get bank loans (no $=0$, yes $=1$ ) & 0.56 & 0.50 & 0.041 \\
\hline & Business decision & $\begin{array}{l}\text { Whether a business strategy decision made } \\
\text { the mistake to bring a loss } \\
\text { to the family economy }(\text { no }=0, \text { is }=1)\end{array}$ & 0.22 & 0.42 & 0.107 \\
\hline \multirow[b]{2}{*}{ Social pressure } & Social status & Social status in the village $($ high $=0$, low $=1$ ) & 0.13 & 0.34 & 0.142 \\
\hline & Social Security & $\begin{array}{l}\text { Whether the lack of basic security (old age, } \\
\text { health insurance, etc.) } \\
\text { led to poor livelihood (no }=0 \text {, is }=1 \text { ) }\end{array}$ & 0.38 & 0.49 & 0.069 \\
\hline \multirow{2}{*}{ Health pressure } & Disease status & $\begin{array}{l}\text { If they have a genetic disorder or are } \\
\text { seriously ill }(\text { no }=0, \text { yes }=1)\end{array}$ & 0.33 & 0.47 & 0.079 \\
\hline & Medical conditions & $\begin{array}{l}\text { Whether the medical system of village health } \\
\text { center is perfect (no }=0 \text {, yes }=1 \text { ) }\end{array}$ & 0.48 & 0.50 & 0.052 \\
\hline
\end{tabular}

\subsubsection{Adaptability}

Adaptability refers to the ability to take effective measures in the face of livelihood pressures $[78,79]$. Referring to the settings of adaptive capacity in studies such as Deng et al. [80], 
Pandey et al. [81], and taking into account the actual situation in the study area, this study planned to measure rural households' adaptive capacity in six dimensions, including natural capital, physical capital, human capital, financial capital, social capital, and livelihood environment (Table 2). Among them, natural capital reflects the degree of dependence on and utilization of natural resources of rural households, which is mainly measured considering the area of cultivated land and forest land per capita. Physical capital refers to the relatively fixed physical means of production and living used by rural households to maintain their livelihood, and it is mainly measured in the present value of fixed assets. Human capital reflects the human resources owned by rural households, which are measured taking into account the proportion of labor force with a higher education level, the number of skilled individuals in the population, etc. Social capital refers to the ability of rural households to adapt to the change of environment by relying on social resources and social relationships, and it mainly reflex the extent of rural households' participation in associations, social networks, and the status of members in public offices. Financial capital refers to the capital that rural households accumulate and move in response to environmental changes in their production and life, and it is mainly measured in terms of the annual per capita cash income and the availability of savings. The livelihood environment refers to the environment that rural households depend on for survival, and it is mainly measured reflecting the status of natural disasters and public services.

Table 2. Evaluation index system of peasant households' adaptability.

\begin{tabular}{|c|c|c|c|c|c|}
\hline Dimensions & Variable & Variable Definition and Description & Mean & SD & Weight \\
\hline \multirow{2}{*}{ Natural capital } & $\begin{array}{l}\text { Per capita cultivated } \\
\text { and area }\end{array}$ & $\begin{array}{l}\text { Ratio of cultivated land area in operation } \\
\text { to total population }\end{array}$ & 0.82 & 2.28 & 0.100 \\
\hline & Per capita forestland area & $\begin{array}{l}\text { Ratio of operating forestland area to } \\
\text { total population }\end{array}$ & 8.38 & 18.73 & 0.090 \\
\hline Physical capital & $\begin{array}{l}\text { Present value of } \\
\text { fixed assets }\end{array}$ & $\begin{array}{l}\text { Present value of agriculture, housing, } \\
\text { and other fixed assets }\end{array}$ & 45.86 & 67.29 & 0.055 \\
\hline \multirow{3}{*}{ Human capital } & Education level & $\begin{array}{l}\text { Ratio of population with high school } \\
\text { education or above } \\
\text { to total population }\end{array}$ & 0.16 & 0.21 & 0.071 \\
\hline & $\begin{array}{l}\text { Proportion of population } \\
\text { in the labor force }\end{array}$ & Labor force to total population ration & 0.58 & 0.30 & 0.016 \\
\hline & Skills & $\begin{array}{l}\text { Ratio of people with skills to } \\
\text { total population }\end{array}$ & 0.24 & 0.24 & 0.049 \\
\hline \multirow{3}{*}{ Social capital } & $\begin{array}{l}\text { Participate in association } \\
\text { organization }\end{array}$ & $\begin{array}{l}\text { Number of associations they } \\
\text { participate in }\end{array}$ & 0.16 & 0.38 & 0.159 \\
\hline & Social network & $\begin{array}{c}\text { Number of families visiting relatives } \\
\text { and friends } \\
\text { during the Spring Festival }\end{array}$ & 5.27 & 8.15 & 0.055 \\
\hline & $\begin{array}{l}\text { Members of } \\
\text { the employment }\end{array}$ & $\begin{array}{c}\text { Whether they have relatives in village or } \\
\text { township cadres or in roles as other } \\
\text { public officials (such as teachers, } \\
\text { civil servants) }\end{array}$ & 1.50 & 2.99 & 0.103 \\
\hline \multirow{2}{*}{$\begin{array}{l}\text { Financial } \\
\text { capital }\end{array}$} & Per capita annual income & $\begin{array}{l}\text { Ratio of total cash income to total } \\
\text { number of persons }\end{array}$ & $16,440.90$ & $18,241.39$ & 0.032 \\
\hline & Deposits & $\begin{array}{l}\text { Whether they have a deposit }(\text { no }=0, \\
\text { yes }=1)\end{array}$ & 0.80 & 0.50 & 0.065 \\
\hline \multirow{3}{*}{$\begin{array}{l}\text { Livelihood } \\
\text { environment }\end{array}$} & Natural disaster situation & $\begin{array}{l}\text { Whether they are in the landslide, debris } \\
\text { flow threat area }(\text { no }=0 \text {, yes }=1)\end{array}$ & 0.80 & 0.40 & 0.019 \\
\hline & Location & $\begin{array}{l}\text { Distance from home to the nearest } \\
\text { main road }\end{array}$ & 233.42 & 661.14 & 0.134 \\
\hline & Public Services & $\begin{array}{l}\text { Distance from home to a } \\
\text { market/market town }\end{array}$ & 5184.65 & 8000.47 & 0.053 \\
\hline
\end{tabular}




\subsubsection{Livelihood Strategies}

Livelihood strategy refers to the collection of measures taken by rural households in response to different livelihood pressures [82]. Referring to the setting of livelihood strategies described in the studies of Xie et al. [83] and Zeng et al. [56], based on the internal resources available to rural households and external livelihood pressures, this study classified livelihood strategies into four types: expanded, adjustment, contractive, and aid. Among them, the expanded livelihood strategy refers to the rural households that increase output or increase the source of income to cope with the livelihood pressure, such as working outside. The adjustment livelihood strategy refers to the rural households that cope with the livelihood pressure by selling assets to adjust the production structure, including mainly selling consumer assets (e.g., grain) and productive assets (e.g., cattle). The contractive livelihood strategy refers to the rural households that reduce consumption to cope with livelihood pressure, e.g., by using their savings. The assistance livelihood strategy refers to the rural households relying on external assistance to cope with livelihood pressure, such as borrowing from friends and relatives, waiting for a state relief, etc.

\subsection{Methods}

\subsubsection{Research Framework}

The adaptive analysis framework was first proposed by Smit et al. [84] and is centered on the adaptive ability, that is, the ability of the system to adapt to stress and recover from the consequences caused by stress $[85,86]$. Its driving factors and determinants are the key factors affecting the adaptability of the system. In the livelihood system, families have the ability to adjust their behavior and adopt necessary strategies to adapt to the disturbances of external pressure $[87,88]$. However, their livelihood adaptation behavior is inevitably influenced by the local natural environment and social policies [89-91], and rural households' adaptability is also influenced by their own assets [92], the influence of external forces [93], and livelihood outputs [94]. Therefore, this study defined livelihood adaptation as a process in which the system uses its own close or reserved resources (assets) to cope with external environmental pressure, dynamically adapt and keep proper state. Based on the analysis framework and the actual situation of the study area, a framework for the study on the adaptability of rural households' livelihood in the earthquake-stricken areas was proposed. It included mainly livelihood pressure, adaptability, and livelihood strategy (Figure 1). The following dissects the possible paths that link them and presents the research hypotheses of this study.

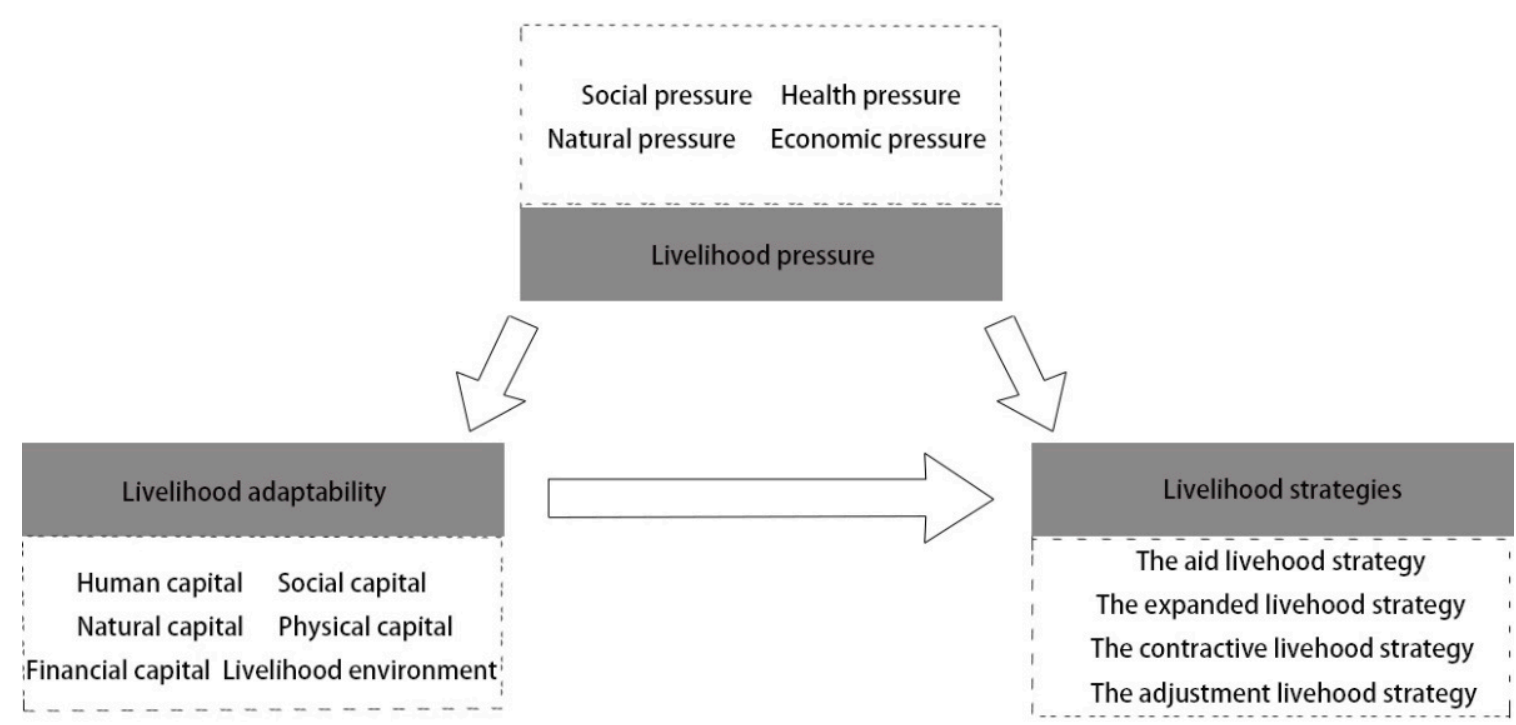

Figure 1. Research framework of livelihood adaptability of rural households in earthquake-stricken areas. 
In terms of natural pressure, facing frequent geological disasters, extreme weather, and other shocks, rural households generally show high vulnerability and usually adopt unsustainable coping strategies (e.g., reducing consumption and using savings) [95]. At this point, the government's transfer payment system response's function is limited, and formal credit cannot be an effective risk management strategy for rural households [96]. Rural households are prone to fall into a vicious circle of "low income-low expenditure-low income" [97], and it is difficult to get rid of the vicious circle, and then they have to seek external help; for instance, they buy insurance [98] and wait for government assistance [99]. Based on this, the following hypotheses were proposed:

Hypothesis 1. When natural pressure is low, the rural households tend to choose the contractive livelihood strategy; when natural pressure is high, the rural households tend to choose the aid livelihood strategy.

In terms of economic pressure, most rural households are passive states [100]. In general, if the economic pressure lasts for a short period of time, rural households resist by reducing expenses and using their savings [56]. If the economic pressure persists for a longer period of time, rural households will generally choose diversified livelihood strategies to withstand shocks [101]. Based on this, the study made the following assumptions:

Hypothesis 2. When economic pressure is low, rural households tend to choose the contractive livelihood strategy; the more economic pressure, rural households tend to choose the expanded livelihood strategy.

As for social pressure, risk retention is the primary option for vulnerable rural households to resist social pressure due to the homogeneity of their social networks and the relatively limited resources available. Reducing consumption and increasing capital stock are some of the effective ways to do so [55]. However, if the social pressure is more than rural households can bear, rural households will tend to borrow to mitigate the shock [102]. Based on this, the study made the following assumptions:

Hypothesis 3. When social pressure is low, the rural households tend to choose the contractive livelihood strategy; the higher the social pressure, the more the rural households tend to choose the aid livelihood strategy.

In terms of health pressure, the risk of serious illness can weaken the competitiveness of rural households' human capital and easily impoverish their families [103]. Many rural households are more vulnerable to health insecurity because they lack the ability to effectively cope with catastrophic risk shocks [104]. At this point, rural households choose to collaborate internally and externally to resist risk shocks [55]. The internal response generally includes reducing expenses and migrating for work, while the external response generally includes borrowing money and seeking medical help. Based on this, the study makes the following assumptions:

Hypothesis 4. When health stress is low, rural households tend to choose the expanded livelihood strategy; the higher the health pressure, the more rural households tend to choose the aid livelihood strategy.

In terms of natural capital, the richer the natural capital, the higher the level of agricultural specialized livelihood activities of rural households. In general, the more abundant natural capital rural households have, the less likely they are to resort to seeking help from relatives and friends to cope with the risks [105], while rural households who lack arable land are more likely to opt for non-farm upgrading strategies or work outside home [106]. At the same time, the stock of natural capital has a positive and significant 
effect on the shift from monoculture to part-time farming [107]. Based on this, the study makes the following assumptions:

Hypothesis 5. When the adaptive capacity of the rural households is weak, they tend to choose the expanded livelihood strategy; when the adaptive capacity is strong, they tend to choose the adjustment livelihood strategy.

In terms of physical capital, selling physical assets and adjusting productive structure can help to effectively resist the impact of external risks in a short time. It has been shown that the more abundant the resources, such as livestock, number of machineries, and types of housing, the more rural households tend to choose agricultural-based livelihood activities [108], which are more conducive to lending and borrowing because of the availability of collateral goods [105]. Based on this, the study makes the following assumptions:

Hypothesis 6. When the rural households' adaptability in physical capital is weak, they tend to choose the adjustment livelihood strategy; and the stronger the adaptability, the more they tend to choose the aid livelihood strategy.

Human capital is the basis of livelihood activities. Rural households with higher levels of education are more likely to choose a variety of livelihood strategies [109] and are more receptive to strategies to adjust the productive structure [110]. Based on this, the study makes the following assumptions:

Hypothesis 7. When the adaptability of rural households in human capital is weak, they tend to choose the adjustment livelihood strategy and the stronger the adaptability, the more they tend to choose the expanded livelihood strategy.

In terms of social capital, strengthening of popularity and social status increases the resources and help available to rural households, and the presence of public officials among relatives and friends improves the rural households' understanding of policies and their grasp of development opportunities [108]. When facing the external risk shock, turning to friends and relatives for help is the usual choice of rural households when they are not able to protect themselves against external shocks by reducing consumption or using their savings [55]. Based on this, the study made the following assumptions:

Hypothesis 8. When the social capital of rural households is weak, they tend to choose the contractive livelihood strategy and the stronger the adaptability, the more they tend to choose the aid livelihood strategy.

In the context of financial capital, the presence and level of household savings determine whether rural households can grasp the development opportunities [111]. In general, diversified livelihood strategies are more conducive to reducing livelihood risks and working outside the home is one of the most important ways for rural households to improve their financial capital [56]. When rural households' agricultural production is insufficient to withstand the impact of external risks, working outside the home and borrowing from relatives and friends are the effective ways to cope with the risk [56]. Based on this, the study makes the following assumptions:

Hypothesis 9. When the adaptability of rural households to financial capital is weak, they tend to choose the expanded livelihood strategy; the stronger the adaptability, the more they tend to choose the contractive livelihood strategy.

With regard to the livelihood environment, frequent natural disasters can drive rural households into poverty [56]. The improvement and upgrading of public services such as roads contribute to saving the cost of agricultural production and information commu- 
nication, and rural households with higher accessibility have more options for economic activities [112]. Based on this, the study makes the following assumptions:

Hypothesis 10. When rural households' adaptability in financial capital is weak, they tend to choose the contractive livelihood strategy; the stronger their adaptability, the more they tend to choose the expanded livelihood strategy.

\subsubsection{Research Methods}

One of the objectives of this study was to explore the relationship among livelihood pressure, adaptability, and livelihood strategies of rural households in earthquake- stricken areas. In order to achieve this goal, we need to obtain the composite indices of livelihood pressure, and adaptive capacity, respectively. Referring to the studies of Peng et al. [25] and $\mathrm{Xu}$ et al. [113], this study intended to use the entropy method to determine the weight of each index and the comprehensive score of each dimension. Compared with qualitative methods, such as the analytic hierarchy process, the entropy method provides more objective and accurate results.

The choice of rural households' livelihood strategy may be influenced by a variety of single factors, or by the interaction of many factors. Therefore, in order to clearly identify the effects of different influencing factors, it was necessary to consider the effects of individual factors on the choice of different livelihood strategies, the magnitude, and direction of their effects when other variables were also influential. The disordered multiclassification logistic regression model is usually used to analyze the influencing factors when the dependent variables are three or more categories and there is no ordinal subrelationship between the categories. Therefore, after obtaining the composite scores for each dimension and using livelihood strategies (categorical and without ordinal relationships) as the dependent variable, we proposed to use the disordered multi-classification logistic regression model to investigate the correlation among livelihood pressure, adaptability, and livelihood strategies. The formula was as follows:

$$
\ln \left[\frac{P(y=j \mid x)}{P(y=J \mid x)}\right]=\alpha_{1}+\sum_{i=1}^{k} \beta_{j i} X_{i}
$$

In Formula (1), $j$ is a type of livelihood strategy; $J$ is the reference type (the expanded livelihood strategy); $\alpha$ is the intercept term; $X_{i}$ is the explanatory variable; $k$ is the number of explanatory variables; $\beta$ is the regression coefficient. When $\beta$ has a positive value, indicating that as the independent variable increases, compared with the $J$, rural households are more likely to choose $j$ as livelihood strategies; when $\beta$ is negative, indicating that as the independent variable increases, rural households are more likely to choose $J$ as livelihood strategies than $j$.

Firstly, regression analysis has incomparable advantages in the processing of large samples. However, in the analysis of small and medium-sized samples, regression analysis cannot provide in-depth and effective statistical explanations due to the limitations of sample size and influencing factors. Secondly, during the regression analysis, there is strong multicollinearity among variables, which may lead to misestimation of independent variables. For example, if an independent variable plays a small role but is in a relatively good model, a regression analysis may conclude that the independent variable has a significant effect on the dependent variable. Finally, the most important feature of regression analysis is that it focuses on the impact of a single variable on the result. This is based on the idea that independent variables are independent of each other, but this does not explain the specific cause of a particular result.

Stata13.0 was used to implement the whole process. 


\section{Results}

\subsection{Descriptive Statistical Analysis}

Figure 2 shows the radar chart of the household livelihood pressure composite index. As can be seen from Figure 2, the livelihood pressure of rural households is dominated by economic pressure (0.4), followed by natural pressure (0.26), health pressure $(0.21)$, and the least social stress (0.13). Figure 3 shows the radar chart of the comprehensive index of farmer's adaptive ability. As can be seen from Figure 3, social capital scored the highest (0.32), followed by livelihood environment ( 0.21$)$, human capital (0.14), financial capital (0.10), and physical capital scored the lowest (0.06).

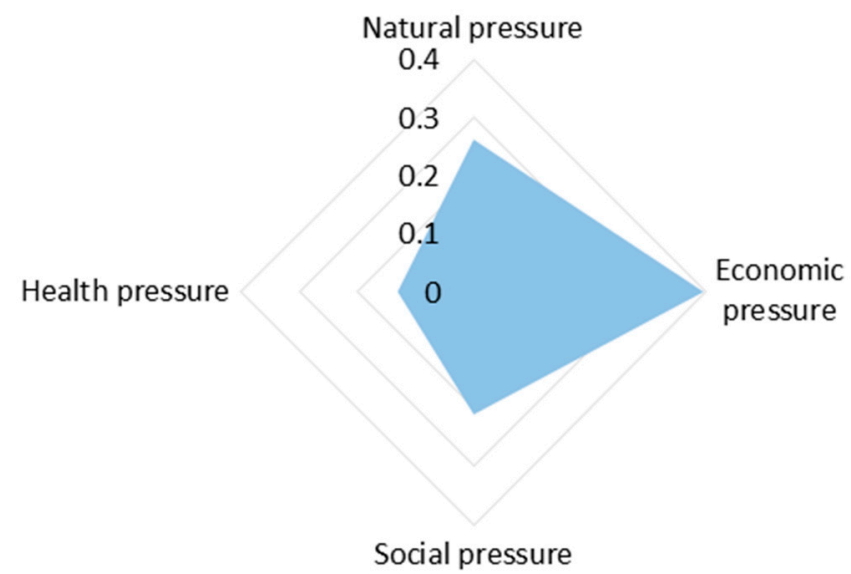

Figure 2. Comprehensive index of livelihood pressure of rural households in earthquake-stricken areas.

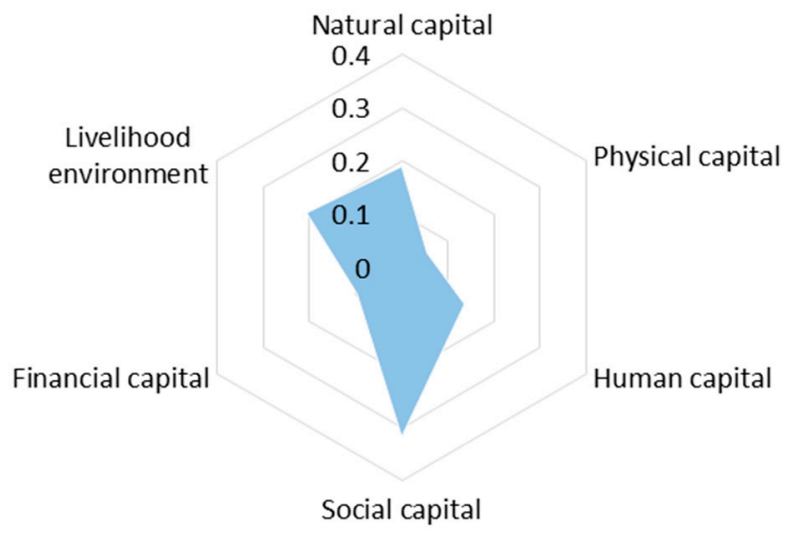

Figure 3. Comprehensive index of adaptability of rural households in earthquake-stricken areas.

When faced with the impact of livelihood pressure, $56.57 \%$ of households adopted the aid livelihood strategy, $24.77 \%$ of households adopted the contractive livelihood strategy, $14.37 \%$ of households adopted the expanded livelihood strategy, and only $3.36 \%$ of households adopted the aid livelihood strategy.

\subsection{Model Results}

Table 3 shows the results of the logistic regression of livelihood stress, adaptability, and livelihood strategy choice, with the model using the expanded livelihood strategy as the reference group. It is clear from the $p$-value corresponding to the overall significance of the model $(0.006<0.01)$ that the model passed the overall significance test. The subsequent specific analysis was as follows:

Inconsistent with the research hypotheses $\mathrm{H} 4$ and $\mathrm{H6}$, the rural households with greater health pressure and higher physical capital tended to choose the expanded livelihood strategy compared with the expanded livelihood strategy. Specifically, all other things 
being equal, for every unit of health pressure and physical capital added, the odds ratio logarithm of rural households choosing an expanded livelihood strategy increased by 23.767 and 333.125 units, respectively.

In disagreement with $\mathrm{H} 4$ and in agreement with $\mathrm{H} 9$, rural households with greater health pressure and higher financial capital were more inclined to choose the contractive livelihood strategy compared with the expanded livelihood strategy. Specifically, for every unit increase in health pressure and financial capital, the odds ratio logarithm of winning the contractive livelihood strategy increased by 8.287 and 16.926 units, respectively.

Table 3. Comprehensive index of adaptability of rural households in earthquake-stricken areas.

\begin{tabular}{cccc}
\hline Variable & $\begin{array}{c}\text { The Adjustment } \\
\text { Livelihood Strategy }\end{array}$ & $\begin{array}{c}\text { The Contractive } \\
\text { Livelihood Strategy }\end{array}$ & $\begin{array}{c}\text { The Aid } \\
\text { Livelihood Strategy }\end{array}$ \\
\hline Natural pressure & 2.009 & -0.913 & -1.132 \\
Economic pressure & $(5.424)$ & $(3.120)$ & $(2.770)$ \\
Social pressure & 1.679 & 0.667 & $-3.750 * *$ \\
& $(3.864)$ & $(1.941)$ & $-1.793)$ \\
Health pressure & 2.771 & -1.994 & $(2.837)$ \\
& $(5.224)$ & $(3.277)$ & $7.341 *$ \\
Natural capital & $-23.767 * *$ & $8.287 *$ & $(4.031)$ \\
& $(11.638)$ & $(4.496)$ & -2.791 \\
Physical capital & -9.359 & -6.922 & $(11.300)$ \\
& $(30.348)$ & $(13.773)$ & -6.967 \\
Human capital & $-333.125 *$ & 7.788 & $-8.452)$ \\
& $(177.883)$ & $(21.108)$ & $(9.873)$ \\
Social capital & -21.796 & -12.556 & 4.990 \\
Financial capital & $(24.085)$ & $(11.207)$ & $(5.741)$ \\
& 1.716 & 5.630 & 4.028 \\
Livelihood environment & $(14.231)$ & $(6.245)$ & $(5.442)$ \\
& -1.310 & $16.926 * * *$ & -3.128 \\
Constant & $(12.490)$ & $(6.091)$ & $(8.052)$ \\
& -1.945 & 4.455 & $1.789 * * *$ \\
LR chi2 $(30)$ & $(15.268)$ & $(8.701)$ & $(0.604)$ \\
Prob $>$ chi2 & 0.291 & -0.211 & \\
Pseudo R2 & $(1.301)$ & $(0.684)$ & \\
\hline
\end{tabular}

Note: The model takes "the expanded livelihood strategy" as the reference group; robust standard errors are in the parentheses; ${ }^{*}, * *$, and ${ }^{* * *}$ represent statistical significance of $0.1,0.05$, and 0.01 , respectively.

Consistent with $\mathrm{H} 2$ and $\mathrm{H} 4$, compared with the expanded livelihood strategy, the households with greater economic pressure are more inclined to choose the expanded livelihood strategy, and the households with greater health pressure are more inclined to choose the aid livelihood strategy. Specifically, for each unit increase in economic pressure, the logit of rural households' winning choice of the expanded livelihood strategy increased by 3.750 units; for each unit increase in health stress, the logit of rural households' winning choice of the aid livelihood strategy increased by 7.341 units.

The study hypothesized that H1, H3, H5, H7, H8, and H10 were not significantly correlated in the current study. Possible reasons for this are the following:

(1) Although the region is under greater natural pressure and the intensity of earthquake disasters and secondary disasters impacts is high, with the continuous progress of the monitoring technology of earthquake disasters in recent years, especially after the Wenchuan and Lushan earthquakes, the government has invested more materials and personnel to help the residents in the disaster areas. Similarly, rural households living in disaster areas for a long time have gradually developed an awareness of disaster avoidance and adopted diversified livelihood strategies to effectively resist pressure after disasters. 
For example, after obtaining loans, rural households used part of them to expand their inputs and part of them to save.

(2) As can be seen in Figure 1, rural households in the study area face the least social pressure. Although the study area is located in a relatively backward southwestern region of China, it is close to the most developed cities in the west. The homogeneity of rural households in this region is weak, and the data showed that rural households are more likely to choose aid livelihood strategies to resist stress. Rural households have strong geographical relationships, blood relationships, and industry-bred relationships, and members borrow from each other more quickly and directly to resist short-term stress.

(3) The natural capital and human capital of rural households in the study area are at the middle level among all the capitals, and most of them have average adaptive capacity of natural and human capital. Under these conditions, natural capital and human capital have limited ability to support rural households to choose different livelihood strategies and need to cooperate with other capital to play a greater role.

(4) The richer the social capital, the richer the popularity and social status. Although the construction of social networks in China's rural areas has become obviously profitoriented since the reform and opening up, rational choice has begun to become an important criterion for Chinese rural households' actions. However, rural households with rich human resources and higher social status have increasing access to resources and assistance. They can make full use of their human and status advantages and choose a variety of measures to resist long-term livelihood pressures. However, the more popular and social status rural households have, the more resources and help they can get. Rural households can take full advantage of their popularity and status and choose various measures to resist the long-term livelihood pressure.

(5) The greater adaptability of the livelihood environment indicates better rural road infrastructure and higher accessibility. Thanks to an infrastructural guarantee for rural households to engage in multiple livelihood strategies, rural households have more opportunities to choose and tend to engage in multiple activities to resist long-term livelihood pressure. The stronger the adaptability of the livelihood environment is, the more perfect the rural road infrastructure is and the higher the accessibility is.

\section{Conclusions and Suggestions}

Based on the survey data of 327 rural households in Wenchuan and Lushan earthquake areas in Sichuan Province, the entropy method was used to measure the livelihood pressure and adaptability scores of rural households, and the disordered multi-classification logistic regression model was established to explore the relationship among livelihood pressure, adaptability, and livelihood strategies. The main conclusions are as follows:

(1) The greatest livelihood pressure faced by rural households is the economic pressure; the social pressure is lower. Rural households have the strongest adaptability in social capital and the worst in financial capital. In the face of livelihood pressure, 56.57\% of the rural households adopted the aid livelihood strategy, while the least of the rural households (3.36\%) chose the adjustment livelihood strategy. This result is different from the one of Zhao et al. (2020), who concluded that farm households in areas with high vulnerability to natural hazards mainly face multiple natural, social, and economic livelihood pressures [88]. Rural households in regions with more serious social and economic pressures have higher human capital, financial capital, and social capital. Rural households with higher social capital prefer to invest more assets and adopt different agricultural production practices to deal with livelihood pressure. The strategy of expansion and adjustment is coordinated. Consistent with the results of Kuang et al. [23], regions with high vulnerability to natural disasters have a more abundant financial and human capital, but he believes that rural households tend to choose to improve planting methods, purchase agricultural insurance, and other measures to increase output by expanding asset input to cope with the pressure. The possible reasons are that the study area locates mainly in Wenchuan and Lushan 
earthquake-stricken areas in Sichuan Province. The Chinese government is committed to the post-disaster reconstruction work and has provided a large number of financial allocations and policy support in various aspects to the disaster areas, thus alleviating the financial risks. However, long-term and sustainable disaster reduction and avoidance have not been realized, and earthquake disasters (including secondary disasters) are more unpredictable than other natural disasters. As rural households have a rich financial capital, they suffer greater losses and economic pressure when facing disasters. At the same time, this region is close to the most developed cities in western China and has geographical advantages, so agriculture is no longer the only choice [16]. Rural households' families also have the habit of saving, and there is a long-term geographical relationship in China's rural areas. Therefore, mutual borrowing among rural households to resist short-term pressure is often the first choice.

(2) When the health pressure is higher, the rural households are more inclined to choose the expanded livelihood strategy, followed by the contractive livelihood strategy and, finally, the aid livelihood strategies. Su et al. found that the higher the health pressure, the more inclined they were to choose to increase sources of income [55], but, inconsistently with the research results of Cooper and Wheeler [114], he believed that rural households were more inclined to choose medical help. The possible reason is that the rural family health care system in developing countries still needs to be improved. While health insurance covers the necessary medical costs, rural families still have to bear part of the costs. At this time, increasing income is a long-term solution to deal with genetic or serious diseases. Working elsewhere also enables sick members to receive better medical care in the city. When coping with the pressure, rural households often consider the inside of the system first and then extend to the outside of the system. How to improve the internal circulation ability of the system is also the focus of research on livelihood adaptability.

(3) The higher the physical capital, the more often the rural households tend to choose the expanded livelihood strategy compared to the adjustment livelihood strategy. This result is similar to the results of Liu et al. [34] but different from the findings of Kuang et al. [23], who found that physical capital is an important factor that promotes rural households to adopt crop variety adjustment strategies. When they have enough physical capital, tangible capital encourages rural households to take measures to adjust their income structure to cope with climate change. The possible reason is that material capital refers to the basic means of production and infrastructure to maintain a livelihood, such as durable goods (agricultural machinery and tools, vehicles) and land. They are indispensable prerequisites for agricultural production, and their conditions must have a significant impact on the livelihood strategy choices of rural households. They can not only increase productivity but also support rural households to stay in agriculture. Generally speaking, the more advanced agricultural production tools rural households have and the more convenient agricultural production infrastructure is, the more incentive rural households have to choose agricultural production.

(4) The higher the financial capital of farm households, the more they prefer contractive livelihood strategies compared to the expanded livelihood strategy. This result is consistent with the findings of Su et al. [102] and inconsistent with the findings of Huang et al. [115], Gwiriri et al. [116], and Liu et al. [15] that the richer the financial capital, the richer their financial expenditures and the more inclined they are to engage in non-agricultural occupations. When rural households in the western mountain areas have more financial capital, they invest more capital and labor to maximize their income from non-agricultural industries. The possible reason is that there is a significant negative correlation between vulnerability and adaptability [117]. The stronger the adaptability of the financial capital is, the fewer risks they are exposed to. Rural households with higher financial capital are more likely to continue to engage 
in the original job rather than entering a new field, because they may bear the pressure brought by a greater uncertainty.

(5) Compared with the aid livelihood strategy, rural households with greater economic pressure are more inclined to choose the expanded livelihood strategy. This result is consistent with the findings of Kinsella et al. [101], but in contrast with the findings of Rissman et al. [118], who argues that signing long-term contracts with people, getting loans, and training in financial literacy, or improving efficiency and productivity, are all effective measures to reduce economic stress. But measures to reduce economic pressure by increasing efficiency and production are limited. This may be because it is difficult for individual rural households to have long-term contracts and obtain loans against their small assets. In addition, although the Chinese government has long insisted on vigorously cultivating high-quality rural households, individual rural households will no longer be willing to continue to engage in small-scale agriculture because of the inevitable rise of farming costs and the narrowing of profit margins. They will often choose to go out to work or invest a large amount of assets to form economies of scale in order to obtain higher profits.

Based on the above analysis, the research can also provide some enlightenment of policies:

First, rural households generally present the characteristics of high economic pressure and poor financial capital adaptability. Therefore, the government can expand the channels for rural households to increase their income by increasing vocational and technical training and developing special industries, so as to improve their financial capital and reduce their economic pressure by increasing their income.

Second, the social pressures rural households face are relatively low and their social capital adaptability is relatively strong. The government can take further measures to promote the maintenance and extension of rural households' geographical consanguinity and industry-bred relationship and effectively alleviate the impact of external livelihood pressure through social networks.

Third, health pressure is an important factor affecting the choice of livelihood strategy. The medical security system implemented by the Chinese government for a long time can help rural households resist health pressure, but the health of rural residents has not been significantly improved, especially for chronic diseases, and there is heterogeneity in the health of different groups [119]. The government can improve the degree of refinement and differentiation of the medical security system and give full consideration to the health pressure faced by different groups of people. We suggest that based on the dynamic big data, such as occupation, age, and health status, a file card should be established to develop personalized medical security services for them. At the same time, routine physical examination can be included in the scope of medical insurance, and rural households can be guided to actively use preventive medical services, early detection, and early treatment, so as to retain talents for rural development and provide talent guarantee for rural revitalization strategy.

Fourth, the more abundant the material capital, the more inclined to increase the asset investment and increase the source of income; the richer the financial capital is, the more inclined it is to reduce expenditure and use savings. This suggests that "hematopoietic poverty alleviation" in China's rural areas can start from the perspective of improving physical capital and financial capital, relying on rural microcredits to enrich physical capital and financial capital to a certain extent, so as to significantly improve the quality and efficiency of financial services. Relevant financial institutions should innovate micro-credit products for rural areas, improve the guarantee system, take full account of the characteristics of long agricultural production cycle and seasonality, and provide differentiated services, so as to provide an impetus for sustainable development.

Fifth, the greater the economic pressure, the more rural households are inclined to expand investment and increase the sources of income. Signing long-term contracts with farmers to provide them with upward mobility and promote agricultural production 
efficiency and output is an effective measure to resist the economy. The government can take further measures to guarantee the circulation of land, encourage mechanized production, make full use of idle resources, promote the large-scale operation of land, and realize the reasonable use of land in colleges and universities, thus providing a guarantee for agricultural scale operation.

Author Contributions: Conceptualization, X.Y. and D.X.; methodology, S.G. and X.D.; software, X.D.; formal analysis, X.Y. and S.G.; investigation, D.X.; writing —original draft preparation, X.Y. and D.X.; writing—review and editing, X.Y. and D.X.; supervision, D.X.; funding acquisition, D.X. All authors have read and agreed to the published version of the manuscript.

Funding: We gratefully acknowledge the financial support from the National Natural Science Foundation of China (41801221), Special Program for Cultivating Excellent Young Talents under the Dual Support Plan of Sichuan Agricultural University, Undergraduate research interest cultivation program in 2021 of Sichuan agricultural university $(2021489 ; 2021488)$, and Fundamental Re-search Funds for the Central Universities (JBK2102018).

Institutional Review Board Statement: Not applicable.

Informed Consent Statement: Not applicable.

Data Availability Statement: The author may provide raw data if necessary.

Acknowledgments: We gratefully acknowledge the financial support from the National Natural Science Foundation of China (41801221), Special Program for Cultivating Excellent Young Talents under the Dual Support Plan of Sichuan Agricultural University, Undergraduate research interest cultivation program in 2021 of Sichuan agricultural university $(2021489$; 2021488), and Fundamental Research Funds for the Central Universities (JBK2102018. The authors also extend great gratitude to the anonymous reviewers and editors for their helpful review and critical comments.

Conflicts of Interest: The authors declare that they have no conflict of interest.

\section{References}

1. Intergovernmental Panel on Climate Change (IPCC). Managing the Risks of Extreme Events and Disasters to Advance Climate Change Adapatation; Cambridge University Press: Cambridge, UK, 2012.

2. Abid, M.; Schneider, U.; Scheffran, J. Adaptation to climate change and its impacts on food productivity and crop income: Perspectives of farmers in rural Pakistan. J. Rural. Stud. 2016, 47, 254-266. [CrossRef]

3. Jezeer, R.E.; Verweij, P.A.; Boot, R.G.; Junginger, M.; Santos, M.J. Influence of livelihood assets, experienced shocks and perceived risks on smallholder coffee farming practices in Peru. J. Environ. Manag. 2019, 242, 496-506. [CrossRef] [PubMed]

4. IDS. Building Climate Change Resilient Cities. IDS Focus Issue 2007, 2, 6.

5. Paul, A.; Deka, J.; Gujre, N.; Rangan, L.; Mitra, S. Does nature of livelihood regulate the urban community's vulnerability to climate change? Guwahati city, a case study from North East India. J. Environ. Manag. 2019, 251, 109591. [CrossRef] [PubMed]

6. Peng, Y.; Zhu, X.; Zhang, F.; Huang, L.; Xue, J.; Xu, Y. Farmers' risk perception of concentrated rural settlement development after the 5.12 Sichuan Earthquake. Habitat Int. 2018, 71, 169-176. [CrossRef]

7. Tian, L.; Yao, P.; Jiang, S.-J. Perception of earthquake risk: A study of the earthquake insurance pilot area in China. Nat. Hazards 2014, 74, 1595-1611. [CrossRef]

8. Archer, D.R.; Fowler, H.J. Characterising flash flood response to intense rainfall and impacts using historical information and gauged data in Britain. J. Flood Risk Manag. 2015, 11, S121-S133. [CrossRef]

9. Arnbjerg-Nielsen, K.; Willems, P.; Olsson, J.; Beecham, S.; Pathirana, A.; Gregersen, I.B.; Madsen, H.; Nguyen, V.-T.-V. Impacts of climate change on rainfall extremes and urban drainage systems: A review. Water Sci. Technol. 2013, 68, 16-28. [CrossRef] [PubMed]

10. Fadhel, S.; Rico-Ramirez, M.A.; Han, D. Sensitivity of peak flow to the change of rainfall temporal pattern due to warmer climate. J. Hydrol. 2018, 560, 546-559. [CrossRef]

11. Li, H.C.; Xie, J.B.; Guo, L.; Kuang, S.F. A review of the study on flash flood early warning in China. Pearl River 2017, 38, $29-35$. (In Chinese)

12. Doyle, E.E.; McClure, J.; Potter, S.H.; Becker, J.; Johnston, D.M.; Lindell, M.K.; Johal, S.; Fraser, S.A.; Coomer, M.A. Motivations to prepare after the 2013 Cook Strait Earthquake, N.Z. Int. J. Disaster Risk Reduct. 2018, 31, 637-649. [CrossRef]

13. Lindell, M.K.; Prater, C.S.; Wu, H.C.; Huang, S.-K.; Johnston, D.M.; Becker, J.; Shiroshita, H. Immediate behavioural responses to earthquakes in Christchurch, New Zealand, and Hitachi, Japan. Disasters 2016, 40, 85-111. [CrossRef] [PubMed]

14. Lo, A.Y.; Cheung, L.T.O. Seismic risk perception in the aftermath of Wenchuan earthquakes in southwestern China. Nat. Hazards 2015, 78, 1979-1996. [CrossRef] 
15. Xu, D.; Peng, L.; Liu, S.; Wang, X. Influences of Risk Perception and Sense of Place on Landslide Disaster Preparedness in Southwestern China. Int. J. Disaster Risk Sci. 2018, 9, 167-180. [CrossRef]

16. Zhou, W.; Guo, S.; Deng, X.; Xu, D. Livelihood resilience and strategies of rural residents of earthquake-threatened areas in Sichuan Province, China. Nat. Hazards 2021, 106, 255-275. [CrossRef] [PubMed]

17. Yin, J.; Qiu, Y.; Zhang, B. Identification of Poverty Areas by Remote Sensing and Machine Learning: A Case Study in Guizhou, Southwest China. Isprs Int. J. Geo-Inf. 2020, 10, 11. [CrossRef]

18. Deng, X.; Xu, D.; Zeng, M.; Qi, Y. Does early-life famine experience impact rural land transfer? Evidence from China. Land Use Policy 2019, 81, 58-67. [CrossRef]

19. Deng, X.; Xu, D.; Zeng, M.; Qi, Y. Does Internet use help reduce rural cropland abandonment? Evidence from China. Land Use Policy 2019, 89, 104243. [CrossRef]

20. Deng, X.; Xu, D.; Zeng, M.; Qi, Y. Does outsourcing affect agricultural productivity of farmer households? Evidence from China. China Agric. Econ. Rev. 2020, 12, 673-688. [CrossRef]

21. Deng, X.; Zeng, M.; Xu, D.; Qi, Y. Does Social Capital Help to Reduce Farmland Abandonment? Evidence from Big Survey Data in Rural China. Land 2020, 9, 360. [CrossRef]

22. Chadalavada, K.; Kumari, B.D.R.; Kumar, T.S. Sorghum mitigates climate variability and change on crop yield and quality. Planta 2021, 253, 1-19. [CrossRef]

23. Kuang, F.; Jin, J.; He, R.; Wan, X.; Ning, J. Influence of livelihood capital on adaptation strategies: Evidence from rural households in Wushen Banner, China. Land Use Policy 2019, 89, 104228. [CrossRef]

24. Kuang, F.; Jin, J.; He, R.; Ning, J.; Wan, X. Farmers' livelihood risks, livelihood assets and adaptation strategies in Rugao City, China. J. Environ. Manag. 2020, 264, 110463. [CrossRef]

25. Peng, L.; Xu, D.; Wang, X. Vulnerability of rural household livelihood to climate variability and adaptive strategies in landslidethreatened western mountainous regions of the Three Gorges Reservoir Area, China. Clim. Dev. 2018, 11, 469-484. [CrossRef]

26. Guo, S.-L.; Li, C.-J.; Wei, Y.-L.; Zhou, K.; Liu, S.-Q.; Xu, D.-D.; Li, Q.-Y. Impact of land expropriation on farmers' livelihoods in the mountainous and hilly regions of Sichuan, China. J. Mt. Sci. 2019, 16, 2484-2501. [CrossRef]

27. Peng, L.; Lin, L.; Liu, S.; Xu, D. Interaction between risk perception and sense of place in disaster-prone mountain areas: A case study in China's Three Gorges Reservoir Area. Nat. Hazards 2017, 85, 777-792. [CrossRef]

28. Khanal, U.; Wilson, C.; Lee, B.L.; Hoang, V.-N. Climate change adaptation strategies and food productivity in Nepal: A counterfactual analysis. Clim. Chang. 2018, 148, 575-590. [CrossRef]

29. Paragbhai, D.P.; Singh, R. Assessment of Agricultural Activities and Market for Local Cropsunder Changing Climate Conditions in Gujarat. Indian J. Econ. Dev. 2019, 15, 351. [CrossRef]

30. Roy, R.; Gain, A.K.; Hurlbert, M.A.; Samat, N.; Tan, M.L.; Chan, N.W. Designing adaptation pathways for flood-affected households in Bangladesh. Environ. Dev. Sustain. 2021, 23, 5386-5410. [CrossRef]

31. Sarker, M.N.I.; Yang, B.; Lv, Y.; Huq, M.E.; Kamruzzaman, M.M. Climate Change Adaptation and Resilience through Big Data. Int. J. Adv. Comp. Sci. Appl. 2020, 11, 533-539.

32. Bunch, M.J.; Pathan, S.; Battaglia, A.G.; Greer-Wootten, B.; Mascoll, A.; Russell, T.; Folkema, J. Quantifying community resilience in South Sudan: The FEED project (Fortifying Equality and Economic Diversification). Ecol. Soc. 2020, 25, 12. [CrossRef]

33. Zhang, Q.; Zhao, X.; Tang, H. Vulnerability of communities to climate change: Application of the livelihood vulnerability index to an environmentally sensitive region of China. Clim. Dev. 2018, 11, 525-542. [CrossRef]

34. Ashikin, A.N.; Diana, M.N.; Siwar, C.; Alam, M.; Yasar, M. Community Preparation and Vulnerability Indices for Floods in Pahang State of Malaysia. Land 2021, 10, 198. [CrossRef]

35. Nguyen, M.-H.; Le, D.P.; Vo, T.T. Vulnerability to Natural Disaster and Welfare Effect: A Case Study of Flood Risk in Vietnam's North Central Region. J. Asian Afr. Stud. 2021, 1. [CrossRef]

36. Satumanatpan, S.; Pollnac, R. Resilience of Small-Scale Fishers to Declining Fisheries in the Gulf of Thailand. Coast. Manag. 2019, 48, 1-22. [CrossRef]

37. Ali, S.; Ghosh, B.; Osmani, A.; Hossain, E.; Fogarassy, C. Farmers' Climate Change Adaptation Strategies for Reducing the Risk of Rice Production: Evidence from Rajshahi District in Bangladesh. Agronomy 2021, 11, 600. [CrossRef]

38. Godde, C.; Dizyee, K.; Ash, A.; Thornton, P.; Sloat, L.; Roura, E.; Henderson, B.; Herrero, M. Climate change and variability impacts on grazing herds: Insights from a system dynamics approach for semi-arid Australian rangelands. Glob. Chang. Biol. 2019, 25, 3091-3109. [CrossRef] [PubMed]

39. Xu, D.; Peng, L.; Liu, S.; Su, C.; Wang, X.; Chen, T. Influences of migrant work income on the poverty vulnerability disaster threatened area: A case study of the Three Gorges Reservoir area, China. Int. J. Disaster Risk Reduct. 2017, 22, 62-70. [CrossRef]

40. Cao, M.; Xu, D.; Xie, F.; Liu, E.; Liu, S. The influence factors analysis of households' poverty vulnerability in southwest ethnic areas of China based on the hierarchical linear model: A case study of Liangshan Yi autonomous prefecture. Appl. Geogr. 2016, 66, 144-152. [CrossRef]

41. Wang, X.; Peng, L.; Xu, D.; Wang, X. Sensitivity of Rural Households' Livelihood Strategies to Livelihood Capital in Poor Mountainous Areas: An Empirical Analysis in the Upper Reaches of the Min River, China. Sustainability 2019, 11, 2193. [CrossRef]

42. Guo, S.; Lin, L.; Liu, S.; Wei, Y.; Xu, D.; Li, Q.; Su, S. Interactions between sustainable livelihood of rural household and agricultural land transfer in the mountainous and hilly regions of Sichuan, China. Sustain. Dev. 2019, 27, 725-742. [CrossRef] 
43. Hoffmann, R.; Muttarak, R. Learn from the Past, Prepare for the Future: Impacts of Education and Experience on Disaster Preparedness in the Philippines and Thailand. World Dev. 2017, 96, 32-51. [CrossRef]

44. Howden, S.M.; Soussana, J.F.; Tubiello, F.N.; Chhetri, N.; Dunlop, M.; Meinke, H. Adapting agriculture to climate change. Proc. Natl. Acad. Sci. USA 2007, 104, 19691-19696. [CrossRef]

45. Liu, Z.; Chen, Q.; Xie, H. Influence of the Farmer's Livelihood Assets on Livelihood Strategies in the Western Mountainous Area, China. Sustainability 2018, 10, 875. [CrossRef]

46. Loison, S.A. Household livelihood diversification and gender: Panel evidence from rural Kenya. J. Rural. Stud. 2019, 69, 156-172. [CrossRef]

47. Simtowe, F. Land Redistribution Impacts on Livelihood Diversification: The case of a market-assisted land redistribution programme in Malawi. Development 2015, 58, 366-384. [CrossRef]

48. Shah, A.A.; Gong, Z.; Khan, N.A.; Khan, I.; Ali, M.; Naqvi, S.A.A. Livelihood diversification in managing catastrophic risks: Evidence from flood-disaster regions of Khyber Pakhtunkhwa Province of Pakistan. Environ. Sci. Pollut. Res. 2021, 1-14. [CrossRef]

49. Khan, I.; Lei, H.; Shah, A.A.; Khan, I.; Muhammad, I. Climate change impact assessment, flood management, and mitigation strategies in Pakistan for sustainable future. Environ. Sci. Pollut. Res. 2021, 1-12. [CrossRef]

50. Nembilwi, N.; Chikoore, H.; Kori, E.; Munyai, R.; Manyanya, T. The Occurrence of Drought in Mopani District Municipality, South Africa: Impacts, Vulnerability and Adaptation. Climate 2021, 9, 61. [CrossRef]

51. Choudhury, M.-U.-I.; Haque, C.E.; Hostetler, G. Transformative learning and community resilience to cyclones and storm surges: The case of coastal communities in Bangladesh. Int. J. Disaster Risk Reduct. 2021, 55, 102063. [CrossRef]

52. Schramski, S.; Keys, E. Smallholder Response to Hurricane Dean: Creating New Human Ecologies through Charcoal Production. Nat. Hazards Rev. 2013, 14, 211-219. [CrossRef]

53. Xu, D.D.; Zhang, J.F.; Liu, S.Q.; Xie, F.T.; Cao, M.T.; Wang, X.L.; Liu, E.L. Study on the Relationship between Livelihood Capital and Livelihood Strategy of farmers in Typical Mountainous Areas of Southwest China. J. Southwest Univ. (Nat. Sci. Ed.) 2015, 37, 118-126. (In Chinese)

54. Xu, H.S.; Yue, Z. Livelihood Capital, Livelihood Risk and Farmer's Livelihood Strategy. Agric. Econ. Prob-Lems. 2012, 33, 100-105. (In Chinese)

55. Su, F.; Tian, X.; Zheng, Y.P. Analysis of the impact of livelihood risk on farmers' coping strategies. J. China Agric. Univ. 2018, 23, 226-240. (In Chinese)

56. Zeng, X.Y.; Guo, S.L.; Deng, X.; Xu, D.D. Livelihood risk and adaptation strategies of farmers in earthquake hazard threatened areas: Evidence from Sichuan province, China. Int. J. Disaster Risk Reduct. 2020, 51, 101971. [CrossRef]

57. Xu, D.; Yong, Z.; Deng, X.; Liu, Y.; Huang, K.; Zhou, W.; Ma, Z. Financial Preparation, Disaster Experience, and Disaster Risk Perception of Rural Households in Earthquake-Stricken Areas: Evidence from the Wenchuan and Lushan Earthquakes in China's Sichuan Province. Int. J. Environ. Res. Public Health 2019, 16, 3345. [CrossRef] [PubMed]

58. Xu, D.; Liu, Y.; Deng, X.; Qing, C.; Zhuang, L.; Yong, Z.; Huang, K. Earthquake Disaster Risk Perception Process Model for Rural Households: A Pilot Study from Southwestern China. Int. J. Environ. Res. Public Health 2019, 16, 4512. [CrossRef]

59. Peng, L.; Tan, J.; Lin, L.; Xu, D. Understanding sustainable disaster mitigation of stakeholder engagement: Risk perception, trust in public institutions, and disaster insurance. Sustain. Dev. 2019, 27, 885-897. [CrossRef]

60. Zhuang, L.; He, J.; Yong, Z.; Deng, X.; Xu, D. Disaster information acquisition by residents of China's earthquake-stricken areas. Int. J. Disaster Risk Reduct. 2020, 51, 101908. [CrossRef]

61. National Bureau of Statistics. Population Age Structure in China 2019. Available online: https:// data.stats.gov.cn/easyquery. $\mathrm{htm}$ ?cn=C01 (accessed on 30 September 2020).

62. Yu, J.; Sim, T.; Guo, C.; Han, Z.; Lau, J.; Su, G. Household adaptation intentions to earthquake risks in rural China. Int. J. Disaster Risk Reduct. 2019, 40, 101253. [CrossRef]

63. Zhou, W.; Ma, Z.; Guo, S.; Deng, X.; Xu, D. Livelihood capital, evacuation and relocation willingness of residents in earthquakestricken areas of rural China. Saf. Sci. 2021, 141, 105350. [CrossRef]

64. Xue, K.; Guo, S.; Liu, Y.; Liu, S.; Xu, D. Social Networks, Trust, and Disaster-Risk Perceptions of Rural Residents in a Multi-Disaster Environment: Evidence from Sichuan, China. Int. J. Environ. Res. Public Health 2021, 18, 2106. [CrossRef] [PubMed]

65. Ma, Z.; Guo, S.; Deng, X.; Xu, D. Community resilience and resident's disaster preparedness: Evidence from China's earthquakestricken areas. Nat. Hazards 2021, 1-25. [CrossRef]

66. Qing, C.; Guo, S.; Deng, X.; Xu, D. Farmers' disaster preparedness and quality of life in earthquake-prone areas: The mediating role of risk perception. Int. J. Disaster Risk Reduct. 2021, 59, 102252. [CrossRef]

67. The National Rural Revitalization Administration. [When Poverty Alleviation is Underway] Dig Out the "Poor Root" and Implant the Industry for Precise Poverty Alleviation. 2015. Available online: http://www.cpad.gov.cn/art/2015/11/23/art_82_4 1424.html (accessed on 1 December 2020). (In Chinese)

68. Almeida, R.K.; Galasso, E. Jump-starting Self-employment? Evidence for Welfare Participants in Argentina. World Dev. 2010, 38, 742-755. [CrossRef]

69. Ellwood, D.T.; Adams, E.K. Medicaid mysteries: Transitional benefits, Medicaid coverage, and welfare exits. Health Care Financ. Rev. 1990, 1990, 119-131. 
70. Yang, H.X.; Huang, K.; Deng, X.; Xu, D.D. Livelihood Capital and Land Transfer of Different Types of Farmers: Evi-dence from Panel Data in Sichuan Province, China. Land 2021, 10, 532. [CrossRef]

71. Xu, D.; Ma, Z.; Deng, X.; Liu, Y.; Huang, K.; Zhou, W.; Yong, Z. Relationships between Land Management Scale and Livelihood Strategy Selection of Rural Households in China from the Perspective of Family Life Cycle. Land 2020, 9, 11. [CrossRef]

72. Xu, D.; Yong, Z.; Deng, X.; Zhuang, L.; Qing, C. Rural-Urban Migration and its Effect on Land Transfer in Rural China. Land 2020, 9, 81. [CrossRef]

73. Xu, D.; Deng, X.; Guo, S.; Liu, S. Labor migration and farmland abandonment in rural China: Empirical results and policy implications. J. Environ. Manag. 2019, 232, 738-750. [CrossRef]

74. Xu, D.; Deng, X.; Huang, K.; Liu, Y.; Yong, Z.; Liu, S. Relationships between labor migration and cropland abandonment in rural China from the perspective of village types. Land Use Policy 2019, 88, 104164. [CrossRef]

75. Xu, D.; Guo, S.; Xie, F.; Liu, S.; Cao, S. The impact of rural laborer migration and household structure on household land use arrangements in mountainous areas of Sichuan Province, China. Habitat Int. 2017, 70, 72-80. [CrossRef]

76. Xu, D.; Zhuang, L.; Deng, X.; Qing, C.; Yong, Z. Media Exposure, Disaster Experience, and Risk Perception of Rural Households in Earthquake-Stricken Areas: Evidence from Rural China. Int. J. Environ. Res. Public Health 2020, 17, 3246. [CrossRef] [PubMed]

77. Yong, Z.; Zhuang, L.; Liu, Y.; Deng, X.; Xu, D. Differences in the Disaster-Preparedness Behaviors of the General Public and Professionals: Evidence from Sichuan Province, China. Int. J. Environ. Res. Public Health 2020, 17, 5254. [CrossRef] [PubMed]

78. Le Dé, L.; Rey, T.; Leone, F.; Gilbert, D. Sustainable livelihoods and effectiveness of disaster responses: A case study of tropical cyclone Pam in Vanuatu. Nat. Hazards 2018, 91, 1203-1221. [CrossRef]

79. Lei, Y.; Wang, J.; Yue, Y.; Zhou, H.; Yin, W. Rethinking the relationships of vulnerability, resilience, and adaptation from a disaster risk perspective. Nat. Hazards 2014, 70, 609-627. [CrossRef]

80. Deng, W.; Sun, B.; Su, Y.; Song, X.Q. Water resource availability and household livelihood adaptation chain framework in mountainous areas of Nepal: A case study in the Koxi River Basin. J. Mt. 2019, 37, 564-574. (In Chinese)

81. Pandey, R.; Jha, S.K.; Alatalo, J.M.; Archie, K.M.; Gupta, A.K. Sustainable livelihood framework-based indicators for assessing climate change vulnerability and adaptation for Himalayan communities. Ecol. Indic. 2017, 79, 338-346. [CrossRef]

82. Bhandari, P.B. Rural livelihood change? Household capital, community resources and livelihood transition. J. Rural. Stud. 2013, 32, 126-136. [CrossRef] [PubMed]

83. Xie, J.H.; Yang, G.Q.; Xu, Y.G. Study on the impact of different land consolidation modes on farmers' livelihood strategies: A case study of Jianghan Plain and some counties and cities in the mountainous area of southwest Hubei Province. China's Rural Econ. 2018, 11, 96-111. (In Chinese)

84. Smit, B.; Burton, I.; Klein, R.J.T.; Street, R. The Science of Adaptation: A Framework for Assessment. Mitig. Adapt. Strat. Glob. Chang. 1999, 4, 199-213. [CrossRef]

85. Intergovernmental Panel on Climate Change (IPCC). Climate Change 2001: Impacts, Adaptation, and Vulnerability. Contribution of Working Group II to the Third Assessment Report of the Intergovernmental Panel on Climate Change, Working Group II Impacts Adaptation and Vulnerability; Cambridge University Press: Cambridge, UK, 2001. [CrossRef]

86. Intergovernmental Panel on Climate Change (IPCC). Climate Change 2014. Impacts, Adaptation, and Vulnerability. Part A: Global and Sectoral Aspects. Contribution of Working Group II to the Fifth Assessment Report; Cambridge University Press: New York, NY, USA, 2014.

87. Chen, J.; Yin, S.; Gebhardt, H.; Yang, X. Farmers' livelihood adaptation to environmental change in an arid region: A case study of the Minqin Oasis, northwestern China. Ecol. Indic. 2018, 93, 411-423. [CrossRef]

88. Zhao, X.Y.; Jie, Y.Q.; He, Y.Q.; He, X.F.; Mu, F.F.; Su, H.Z.; Lan, H.X. Livelihood adaptability of farmers in key ecological function areas under multiple pressures: A case study of the Yellow River water supply area in Gannan. Popul. Re. Environ. 2020, 30, 140-149. (In Chinese)

89. Voss, R.C. On- and non-farm adaptation in Senegal: Understanding differentiation and drivers of farmer strategies. Clim. Dev. 2021, 1-15. [CrossRef]

90. Mabon, L.; Nguyen, S.T.; Pham, T.T.; Tran, T.T.; Le, H.N.; Doan, T.T.H.; Hoang, T.N.H.; Mueller-Hirth, N.; Vertigans, S. Elaborating a people-centered approach to understanding sustainable livelihoods under climate and environmental change: Thang Binh District, Quang Nam Province, Vietnam. Sustain. Sci. 2021, 16, 221-238. [CrossRef]

91. Mbanze, A.A.; da Silva, C.V.; Ribeiro, N.S.; Silva, J.F.; Santos, J.L. A Livelihood and Farming System approach for effective conservation policies in Protected Areas of Developing Countries: The case study of the Niassa National Reserve in Mozambique. Land Use Policy 2020, 99, 105056. [CrossRef]

92. Nsubuga, F.N.W.; Mearns, K.F.; Davis, N.C.; Kalumba, A.M.; Komen, K. Exploring the influence of climate change and capital assets on livelihood formations in central region of Uganda. Environ. Dev. Sustain. 2021, 23, 9223-9242. [CrossRef]

93. Gomez, M.L.A.; Adelegan, O.J.; Ntajal, J.; Trawally, D. Vulnerability to coastal erosion in The Gambia: Empirical experience from Gunjur. Int. J. Disaster Risk Reduct. 2020, 45, 101439. [CrossRef]

94. Mahmood, N.; Arshad, M.; Kächele, H.; Ullah, A.; Müller, K. Economic efficiency of rainfed wheat farmers under changing climate: Evidence from Pakistan. Environ. Sci. Pollut. Res. 2020, 27, 34453-34467. [CrossRef]

95. Liu, K.B.; Xiong, X.; Lie, F.Y. Analysis of farmers' risk avoidance and response to natural disasters in poor areas. Agric. Resour. Regi. 2020, 41, 289-296. (In Chinese) 
96. Zhang, L.Y.; Xu, M.M.; Liu, J.J. Impact of natural disasters and farmers' access to credit: An empirical study based on CFPS data. China's Rural Econ. 2019, 3, 36-52. (In Chinese)

97. Liu, H.Y. Study on the Rural Development of Wenchuan Disaster Area in the Post-reconstruction Era - Based on the Theoretical Analysis of the Practical Capability of Rural Residents. Soc. Sci. Res. 2011, 2, 27-32. (In Chinese)

98. Turvey, C.G.; Kong, R. Business and financial risks of small farm households in China. China Agric. Econ. Rev. 2009, 1, 155-172. [CrossRef]

99. Deng, S.Y. The Problem of Philanthropic Risk and the Balance of Fair Efficiency in Catastrophe Insurance; Huazhong University of Science and Technology: Wuhan, China, 2010. (In Chinese)

100. Wu, L.N.; Li, X.J.; Qiao, J.J. Analysis on the Behavior of Farmers' Risk Decision-making in Agricultural Production in Underdeveloped Agricultural Areas-A Case Study of Sying Pepper Growers in Zhecheng County under the Influence of Financial Crisis. Henan Soc. Sci. 2012, 20, 59-62. (In Chinese)

101. Kinsella, J.; Wilson, S.; De Jong, F.; Renting, H. Pluriactivity as a Livelihood Strategy in Irish Farm Households and its Role in Rural Development. Sociol. Rural. 2000, 40, 481-496. [CrossRef]

102. Su, F.; Saikia, U.; Hay, I. Impact of Perceived Livelihood Risk on Livelihood Strategies: A Case Study in Shiyang River Basin, China. Sustainability 2019, 11, 3349. [CrossRef]

103. Su, F.; Ma, N.N.; Zheng, Y.P. Livelihood Risk Assessment and Its Influence on Well-Being of Farmers in Shiyang River Basin, Gansu Province. Glacial Permafr. 2019, 42, 719-730. (In Chinese)

104. Islam, A.; Maitra, P. Health shocks and consumption smoothing in rural households: Does microcredit have a role to play? J. Dev. Econ. 2012, 97, 232-243. [CrossRef]

105. Zhao, X.Y.; Zhao, H.L.; Liu, C.F. Livelihood Risks and Countermeasures of Farmers in the Lower Shiyang River: A Case Study of Minqin Oasis District. Geogr. Res. 2015, 34, 922-932. (In Chinese)

106. Tu, L. Livelihood Capital, Livelihood Index and Livelihood Strategy of Farmers: An Empirical Analysis Based on CLDS Household Data. Rural Econ. 2018, 8, 76-83. (In Chinese)

107. Ding, E.Q.; Dong, H.B.; Hou, X.Y.; Li, X.L.; Yin, Y.T. An empirical study on the impact of livelihood capital on livelihood strategy choice of herdsmen based on multinomial Logit model. Chin. Agric. Sci. Bull. 2020, 36, 150-158. (In Chinese)

108. Yang, S.L.; Zhao, W.J.; Xu, R.; Huang, X.X. Analysis on the mechanism of farmers' livelihood strategy selection in Yuanjiang dry-hot valley: A case study of Xinping County. Resour. Environ. Arid Area 2016, 30, 19-23. (In Chinese)

109. Wu, Y.H.; Su, R.N.; Xu, L.L.; Yang, Z.J.; Wang, M.L. Study on the Relationship between Livelihood Capital and Livelihood Strategy of Herdsmen-A Case Study of Xilinhot City and West Ujimqin Banner in Inner Mongolia. Agrotech. Econ. 2017, 7, 71-77. (In Chinese)

110. Zhao, X.Y.; Wang, Y.R.; Zhang, Q.; Luo, L.; Xue, B. Climate change adaptation strategy selection of farmers in Shiyang River Basin. J. Northwest Norm. Univ. (Nat. Sci. Ed.) 2016, 52, 127-134. (In Chinese)

111. Wu, J.L.; Liu, S.L.; Zhou, C.S. Adaptability of Farmers in Traditional Villages under the Background of Rural Tourism Development: A Case Study of 4 Villages in Zhangiiajie. Econ. Geogr. 2017, 37, 232-240. (In Chinese)

112. An, S.W.; Fan, X.S. Household livelihood strategy based on income source and its influencing factors: A case study of Henan Province. Econ. Fabr. 2017, 35, 29-34. (In Chinese)

113. Xu, D.; Liu, E.; Wang, X.; Tang, H.; Liu, S. Rural Households' Livelihood Capital, Risk Perception, and Willingness to Purchase Earthquake Disaster Insurance: Evidence from Southwestern China. Int. J. Environ. Res. Public Health 2018, 15, 1319. [CrossRef] [PubMed]

114. Cooper, S.J.; Wheeler, T. Rural household vulnerability to climate risk in Uganda. Reg. Environ. Chang. 2017, 17, 649-663. [CrossRef]

115. Huang, L.; Yang, L.; Tuyến, N.T.; Colmekcioglu, N.; Liu, J. Factors influencing the livelihood strategy choices of rural households in tourist destinations. J. Sustain. Tour. 2021, 1-23. [CrossRef]

116. Gwiriri, L.; Bennett, J.; Mapiye, C.; Burbi, S. Emerging from Below? Understanding the Livelihood Trajectories of Smallholder Livestock Farmers in Eastern Cape Province, South Africa. Land 2021, 10, 226. [CrossRef]

117. Salam, R.; Islam, A.R.M.T.; Shill, B.K.; Alam, G.M.; Hasanuzzaman, M.; Hasan, M.; Ibrahim, S.M.; Shouse, R.C. Nexus between vulnerability and adaptive capacity of drought-prone rural households in northern Bangladesh. Nat. Hazards 2021, 106, 509-527. [CrossRef]

118. Rissman, A.R.; Geisler, E.; Gorby, T.; Rickenbach, M.G. "Maxed Out on Efficiency": Logger Perceptions of Financial Challenges Facing Timber Operations. J. Sustain. 2020, 1-19. [CrossRef]

119. Yan, H.T.; Yang, S.P. Empirical study on the health effects of medical security system on rural residents. Stat. Decis. Mak. 2021, 37, 95-99. (In Chinese) 